\title{
A green approach for the treatment of dye and surfactant contaminated industrial wastewater
}

\author{
$\ddot{U} . D . G \ddot{u} l^{a, b *}$

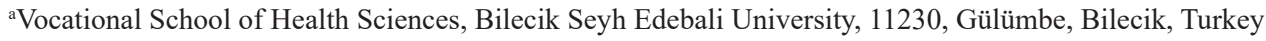

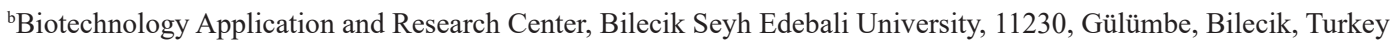 \\ *e-mail: ulkuyedudugul@gmail.com; ulkuyedudu.gul@bilecik.edu.tr
}

Received: December 24, 2018 - Accepted: March 7, 2019 - Distributed: August 31, 2020

(With 4 figures)

\begin{abstract}
Synthetic dyes, particularly reactive and acid dyes, are commonly used in the textile industry because of their advantages as excellent color fastness and brightness. Also, surfactants are used for an increment of coloring success in the textile industry. One of the major problems concerning textile wastewater is the treatment of the effluents containing both dyes and surfactants. Biological treatment systems are recommended as useful, economic and eco-friendly methods for treatment of industrial wastewater. The purpose of this study was to investigate the binary removal of a textile dye and a surfactant by growing Aspergillus versicolor culture in molasses medium. The effect of dye and surfactant concentration on the removal of dye and surfactant was determined. This study resulted that $100 \%$ of the surfactant and dye molecules removed together with the formation of a dye-surfactant complex by fungus. It is concluded that binary removal systems are very efficient for industrial wastewater treatment.
\end{abstract}

Keywords: biological treatment, fungi, surfactant, textile dye.

\section{Uma abordagem verde para o tratamento de águas residuais industriais contaminadas por tintas e surfactantes}

\begin{abstract}
Resumo
Os corantes sintéticos, particularmente corantes reativos e ácidos, são comumente usados na indústria têxtil devido às suas vantagens como excelente solidez da cor e brilho. Além disso, os surfactantes são usados para incrementar o sucesso da coloração na indústria têxtil. Um dos principais problemas relativos às águas residuais têxteis são o tratamento dos efluentes contendo corantes e surfactantes. Os sistemas de tratamento biológico são recomendados como métodos úteis, econômicos e ecológicos para o tratamento de efluentes industriais. O objetivo deste estudo foi investigar a remoção binária de um corante têxtil e um surfactante, cultivando a cultura Aspergillus versicolor em meio de melaço. O efeito das concentrações de corante e surfactante nas remoções de corante e surfactante foi determinado. Este estudo resultou na remoção de $100 \%$ das moléculas de surfactante e corante juntamente com a formação de um complexo corante-surfactante por fungos. Conclui-se que os sistemas de remoção binária são muito eficientes no tratamento de efluentes industriais.
\end{abstract}

Palavras-chave: tratamento biológico, fungos, surfactante, corante têxtil.

\section{Introduction}

The augmentation of industrial activities are important for the economic development of countries, but they also cause environmental and health problems due to their toxic effluents. Particularly, dyes and surfactants are found together as toxic pollutants in the content of the industrial wastewater. There are some advantages of using synthetic dyes such as high stability to light, temperature, detergent and microbial attack and variety in color while comparing with natural dyes (Rodríguez Couto, 2009). Especially reactive and acid dyes are extensively used in the coloring of textile products. Reactive Blue 19 (RB 19) has been widely used as a model compound for anthraquinone-type dye in decolorization studies. It is the raw material in the production of polymeric dyes and, as a derivative of the two ringed $\mathrm{PAH}$, represents the main component of toxic and recalcitrant organic pollutants (Hadibarata et al., 2012). Acid Blue 83 ( $\mathrm{AB} 83$ ) is commonly used in the textile industry, but recent studies emphasized the carcinogenic and mutagenic properties of this dye (Karthick et al., 2018).

Surfactants are extensively used in industries such as detergent and the effluents of these industries contain high amounts of surfactants. In addition to this, surfactant 
polluted water affected living organisms negatively. For instance, Heidari and Kahrizi (2018) reported that detergents consisted of surfactants, contaminated water, and this water reduced plant growth. Also, surfactants are used as wetting or penetrating agents in coloring technologies (Liu et al., 2005). The interactions of surfactants with dyes play a very important role in achieving an effective coloring process (Alehyen et al., 2010). Due to their widespread applications, the investigations of interactions between organic molecules and surfactants in various environments have gained in importance. Recently, Khalladi et al. (2018) showed that usage of surfactants enhanced the removal of polycyclic aromatic hydrocarbons (PAH) from the soil by soil washing process. Also, the usage of surfactants in dye removal from wastewater treatment gains importance (Karatay et al., 2014). The cationic surfactant called dodecyltrimethylammonium bromide (DTAB) has been used in this study. The molecular structure of $\mathrm{AB} 83$, RB 19 and DTAB are given in Figure 1. Every year tons of effluents containing dyes and surfactants are discharged into the receiving environment (Maas and Chaudhari, 2005).

Recently, the development of inexpensive and environmentally friendly methods for the treatment of wastewater containing pollutants becomes important (Ramírez et al., 2018). Physical and chemical treatment

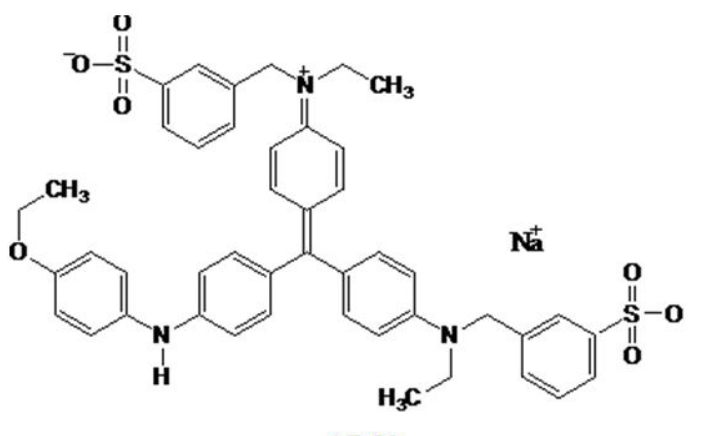

AB 83

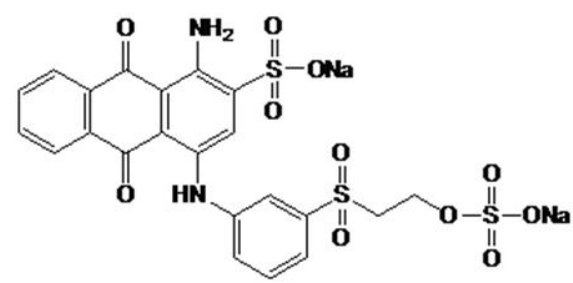

RB 19

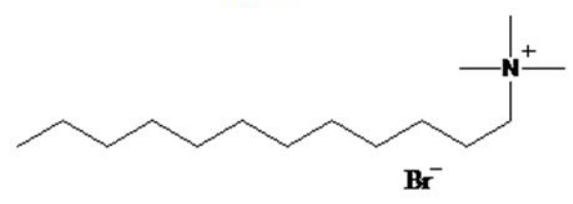

DTAB

Figure 1. The molecular structure of Acid Blue 83 (AB 83), Reactive Blue 19 (RB 19) and Dodecyltrimethylammonium bromide (DTAB). methods are expensive but biological treatment is cost-effective and eco-friendly (Freitas et al., 2018). The use of biological materials as bacteria, fungi, yeast, and algae for removal of pollutants is defined as biological treatment. The recent studies focused on the usage of fungi due to their metabolic variety and low-cost availability. In addition to this, fungi can be tolerated in negative conditions compared with other organisms and fungi are useful in biological wastewater treatment technologies. There are some studies about the removal of dyes from wastewater by fungi (Przystaś et al., 2013). There are a few researchers studied the removal of dyes by the usage of surfactants from industrial effluents (Ouni et al., 2015). Previously, Gül and Dönmez (2014) showed that cationic surfactant DTAB enhanced removal of Remazol Blue dye which is the form of commercial product, not a pure form. A review of the literature revealed that no reports have been published on decolorization of $\mathrm{AB} 83$ and RB 19 in the pure form using DTAB. Also, there is not any study focused on the binary removal of dyes and surfactants together. The aim of this study is to remove both dyes and surfactants in the systems contained fungi. Also, it is intended to monitor the removal of the surfactant molecule in an easy method.

\section{Material and Methods}

\subsection{Preparation of dye and surfactant solutions}

Acid Blue 83 (AB 83) and Reactive Blue 19 (RB 19) were obtained from Sigma in pure form. The dye stock solution was prepared by dissolving the powdered dyestuff in distilled water to a final concentration of $2 \% \mathrm{w} / \mathrm{v}$. The cationic surfactant dodecyltrimethylammonium bromide (DTAB) was supplied by Fluka. The stock surfactant solutions were prepared at $1.0 \mathrm{~g} / \mathrm{L}$ concentration by dissolving weighed amounts in double-distilled water. Appropriate volumes of the stock solutions were added to the media. The properties of dyes and surfactant used in this study were given in Table 1.

\subsection{Microorganism and growth conditions}

The filamentous fungus Aspergillus versicolor, which was isolated from the soil samples of Batman, Turkey (Taştan et al., 2010), was used in this study. The pure cultures were kept at $4{ }^{\circ} \mathrm{C}$ and were transferred to molasses media containing dye every 3 months, immediately after their arrival at the laboratory. The growth medium was composed of beet molasses solution (approximately equivalent to $10 \mathrm{~g} / \mathrm{L}$ sucrose), $1.0 \mathrm{~g} / \mathrm{L}\left(\mathrm{NH}_{4}\right)_{2} \mathrm{SO}_{4}$ and $0.5 \mathrm{~g} / \mathrm{L} \mathrm{KH}_{2} \mathrm{PO}_{4}$. The $\mathrm{pH}$ was adjusted to the desired value with $0.1 \mathrm{M} \mathrm{NaOH}$ using $\mathrm{pH}$ meter (Hanna). The medium was autoclaved $\left(121^{\circ} \mathrm{C}\right.$ for $\left.15 \mathrm{~min}\right)$ and then a defined quantity of dye and surfactant solutions with known concentrations were added to the growth medium.

In order to acclimate fungal cells the fungal biomass was added into the media that contained dye and surfactant before decolorization expertiments, then activated fungal biomass $(2 \mathrm{~mL})$ was inoculated into experimental flasks $(250 \mathrm{~mL})$ for decolorization assays. The fungal cells were 
Table 1. The properties of Acid Blue 83 (AB 83), Reactive Blue 19 (RB 19), Dodecyltrimethylammonium bromide (DTAB).

\begin{tabular}{lccc}
\hline \multicolumn{1}{c}{ Name } & Synonym & Molecular Formula & Molecular Weight (g/mol) \\
\hline $\begin{array}{l}\text { Acid Blue 83 } \\
(\mathrm{AB} \mathrm{83)}\end{array}$ & Coomassie Blue & $\mathrm{C}_{45} \mathrm{H}_{44} \mathrm{~N}_{3} \mathrm{Na}_{7} \mathrm{~S}_{2}$ & 825.97 \\
$\begin{array}{l}\text { Reactive Blue 19 } \\
\text { (RB 19) }\end{array}$ & Remazol Brillant Blue R & $\mathrm{C}_{22} \mathrm{H}_{16} \mathrm{~N}_{2} \mathrm{Na}_{2} \mathrm{O}_{11} \mathrm{~S}_{3}$ & 626.54 \\
$\begin{array}{l}\text { Dodecyltrimethylammonium } \\
\text { bromide } \\
\text { (DTAB) }\end{array}$ & $\begin{array}{c}\text { Lauryltrimethylammonium } \\
\text { bromide }\end{array}$ & $\mathrm{CH}_{3}\left(\mathrm{CH}_{2}\right)_{11} \mathrm{~N}_{\left(\mathrm{CH}_{3}\right)_{3} \mathrm{Br}}$ & 308.34 \\
\hline
\end{tabular}

inoculated twice into $250 \mathrm{~mL}$ Erlenmeyer flasks containing $100 \mathrm{~mL}$ of molasses medium at $25^{\circ} \mathrm{C}$ on a rotary shaker (New Brunswick Scientific Innova 4230) at $100 \mathrm{rpm}$ in 24 hours incubation period.

\subsection{The effect of surfactant on the optical density of dyes}

To determine the changes in the optical density of Acid Blue 83 (AB 83) and Reactive Blue 19 (RB 19) by the effect of the DTAB concentration, $0,0.1,0.5,1$ and 2 mM DTAB were added to $10 \mathrm{~mL}$ molasses medium with $5 \mathrm{mg} / \mathrm{L}$ dye. Then, $2 \mathrm{~mL}$ of samples were scanned at $400-700 \mathrm{~nm}$ in Perkin Elmer Lambda 25 model spechtrophotometer. Molasses medium was used as a blank.

\subsection{The effect of a cationic surfactant on fungal decolorization}

To examine the effect of a cationic surfactant (DTAB) on anionic dye (RB 19) removal by A. versicolor, $0.5 \mathrm{mM}$ DTAB was added to $250 \mathrm{~mL}$ Erlenmeyer flasks containing $100 \mathrm{~mL}$ molasses medium with $100 \mathrm{mg} / \mathrm{L}$ dye at $\mathrm{pH} 6$. Flasks with molasses medium ( $\mathrm{pH} 6$ ) and $0.5 \mathrm{mM}$ surfactants were used as a control.

\subsection{Decolorization assays}

The effect of initial $\mathrm{pH}$ on dye decolorization and dye-surfactant interactions were investigated at pHs 3, 4, 5, 6 and 7 in molasses medium supplied with $100 \mathrm{mg} / \mathrm{L}$ dye and $0.5 \mathrm{mM}(154.2 \mathrm{mg} / \mathrm{L})$ DTAB. The dye- surfactant interactions were monitored by the flasks contained dye and surfactant at different $\mathrm{pH}$ values.

To examine the effect of surfactant concentration on bioremoval, $A$. versicolor was inoculated into molasses media containing $0.05 \mathrm{mM}(15.42 \mathrm{mg} / \mathrm{L}), 0.1 \mathrm{mM}(30.8 \mathrm{mg} / \mathrm{L})$, $0.5 \mathrm{mM}(154.2 \mathrm{mg} / \mathrm{L}), 1 \mathrm{mM}(308.4 \mathrm{mg} / \mathrm{L})$ and $2 \mathrm{mM}$ $(616.8 \mathrm{mg} / \mathrm{L})$ DTAB with $100 \mathrm{mg} / \mathrm{L}$ dye. The effect of surfactant and dye concentrations on dye- surfactant interactions was determined by $0,0.05,0.1,0.5,1,2 \mathrm{mM}$ DTAB with 50, 100, 200, 400, 600 and $800 \mathrm{mg} / \mathrm{L}$ dye.

Un-inoculated Erlenmeyer flasks containing dye and surfactant were used as control samples to observe any reactions of the media with the dye and surfactant. Each of these experiments and the measurements described below to follow the daily changes in the samples throughout the incubation period were performed in triplicate.

\subsection{Analytical methods}

During the incubation period (24 hours), a $3 \mathrm{~mL}$ sample was taken daily from each flask to remove suspended biomass. The concentration of Acid Blue 83 (AB 83) and
Reactive Blue 19 (RB 19) were determined by measuring the absorbance at $560 \mathrm{~nm}$ and $590 \mathrm{~nm}$. The surfactant RB 19 dye complex was determined by reading absorbance at $640 \mathrm{~nm}$ where the maximum absorption peaks exist for the dye-surfactant complex. Cell-free molasses medium was used as a blank.

Absorbance measurements and centrifugation were performed using a Perkin Elmer Lambda 25 model spectrophotometer and Sigma-D-37520 model centrifuge, respectively.

The effect of surfactant on dye removal properties of A. versicolor and surfactant- dye interactions were investigated in a batch system as a function of initial $\mathrm{pH}$ as well as dye and surfactant concentrations. The percentage removal of dye was calculated from

Dye Removal $(R \%)=\left(A_{o}-A_{f}\right) / A_{o} x 100$

In the Equation 1, $\mathrm{A}_{\mathrm{o}}$ and $\mathrm{A}_{\mathrm{f}}$ the initial and final absorbance values, respectively.

\section{Results and Discussion}

The properties of dyes and surfactant used in this study were given in Table 1.

\subsection{The effect of surfactant on the optical density of dyes}

The effect of surfactant concentration on the optical density of $\mathrm{AB} 83$ was determined at different surfactant concentrations as $0.1,0.5,1$ and $2 \mathrm{mM}$. Also, the optical density of dye without surfactant was scanned from 400 to $700 \mathrm{~nm}$ wavelength as a control. As seen in Figure 2, the maximum peak of $\mathrm{AB} 83$ dye molecule absorbance was observed at $560 \mathrm{~nm}$. On the other hand in the presence of $0.1 \mathrm{mM}$ DTAB, there was a new peak occurred at $600 \mathrm{~nm}$. Also, the peak formation at $600 \mathrm{~nm}$ became significant with the increment of surfactant concentrations (Figure 2). The occurrence of this peak was assumed to the formation of the dye-surfactant complex. While the concentration of DTAB molecule increased, the occurrence of the second peak became significant at $600 \mathrm{~nm}$. AB 83 is an anionic dye molecule and DTAB is a cationic surfactant molecule, so it is expected that the electrochemical interactions occurred between dye and surfactant molecules. It was considered that the surfactant-dye complex formation observed at $600 \mathrm{~nm}$ and the amount of surfactant molecule may be monitored by the changes in this second peak. The peak 
at $600 \mathrm{~nm}$ has provided to monitor the presence of a surfactant molecule in the solution.

Similarly, with AB 83 dye measurements, there was a new peak formation was observed in the optical density of RB 19 at $640 \mathrm{~nm}$ in the presence of DTAB (Figure 3). This peak occurrence was related to the presence of DTAB. The changes in this peak showed the changes of DTAB concentration and the removal of DTAB could be monitored by monitoring the changes in this peak.

As seen in Figure 1 and Table 1, AB 83 dye has two and RB 19 dye has three sulfonate groups and it was reported that sulfonate groups had negative charges in aqueous solutions (Caner et al., 2009). Both AB 83 and RB 19 had anionic nature and there were electrostatic interactions between dyes and the cationic surfactant DTAB. It is reported that a cationic surfactant affected the electronic absorption

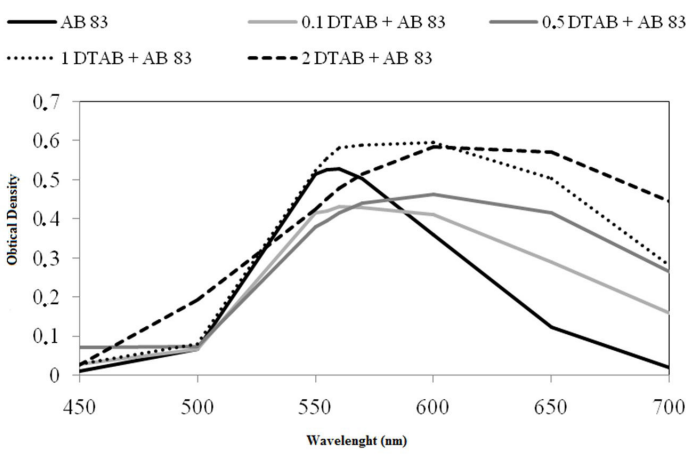

Figure 2. The changes in the optical density of $A B 83$ by DTAB.

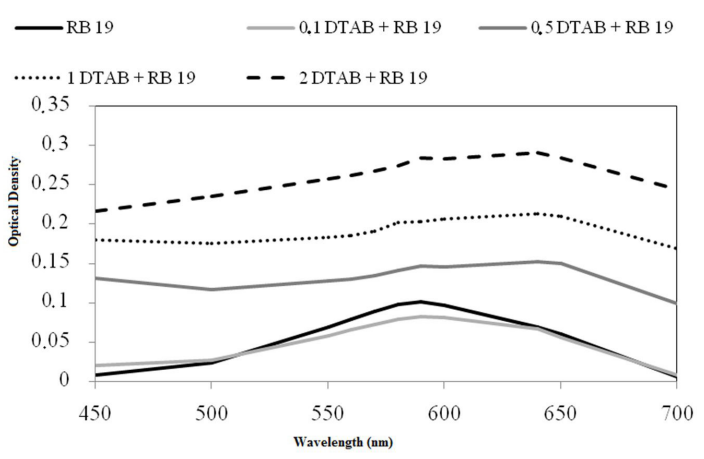

Figure 3. The changes in the optical density of RB 19 by DTAB. spectra of anionic dye solution due to the formation of surfactant-dye complex and the value of absorption spectra was decreased in the presence of a surfactant, but there was not any information about the new peak formation in the study of Akbaş and Taner (2013). It was considered that these electrostatic attractions caused the formation of the dye-surfactant complex and the optical density of two dyes was decreased in the presence of a surfactant. In addition to this, the dye-surfactant complex formation with RB 19 was more stable than $\mathrm{AB} 83$ due to the number of sulfonate groups. The peaks of DTAB-RB 19 dye complex was very significant (Figure 3), the continuous experiments were designed with RB 19 and DTAB in order to monitor the changes in DTAB concentration.

\subsection{The effect of $\mathrm{pH}$ on dye and surfactant removal by fungi}

The removal of dye was monitored at $590 \mathrm{~nm}$ after 24 hours in the absence and presence of surfactant DTAB, on the other hand, the binary removal of the dye-surfactant complex was followed at $640 \mathrm{~nm}$. As seen in Figure 4, the fungus removed $10 \%$ of dye after 24 hours of incubation in the absence of DTAB at $\mathrm{pH} 4$ maximally. It was reported that fungal growth was related to the decolorization activity of fungi (Borchert and Libra, 2001). Also, it was known that maximum fungal growth occurred at $\mathrm{pH}$ 4-6 (Rousk et al., 2009). On the other hand, the same fungus showed $100 \%$ dye removal in the presence of surfactant at $\mathrm{pH} 3$.

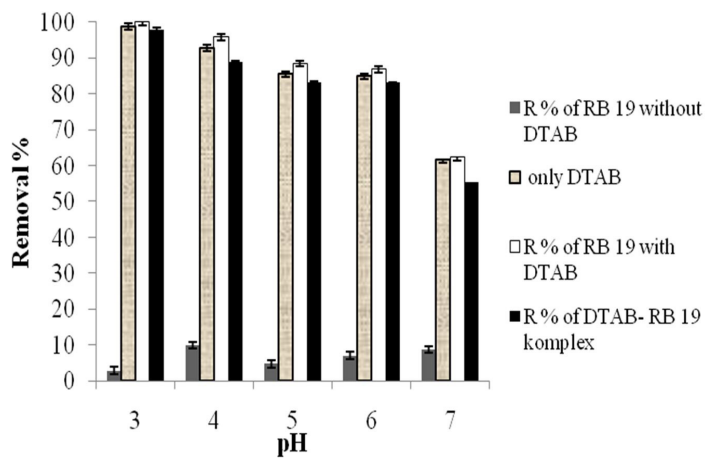

Figure 4. The effect of $\mathrm{pH}$ on Removal $(\mathrm{R} \%)$ in molasses medium by $A$. versicolor $(\mathrm{R} \%$ of RB 19: Removal of dye by only fungi, R\% of RB 19 with DTAB: Removal of dye by fungi in the presence of DTAB, R \% of DTAB- RB 19 complex: Removal of dye-surfactant complex by fungi, DTAB $=$ Dodecyl Trimethyl Ammonium bromide).

Table 2. The effect of surfactant and dye concentrations on RB 19 Removal rate (R\%).

\begin{tabular}{ccccccc}
\hline \multirow{2}{*}{$\mathbf{C}_{\mathbf{0} \text { RBBR }}(\mathbf{m g} / \mathbf{L})$} & \multicolumn{7}{c}{$\mathbf{C}_{\mathbf{0} \text { DTAB }}(\mathbf{m M})$} \\
\cline { 2 - 6 } & $\mathbf{0 . 0 5}$ & $\mathbf{0 . 1}$ & $\mathbf{0 . 5}$ & $\mathbf{1}$ & $\mathbf{2}$ & \\
\hline 100 & 2.63 & 4.94 & 98.9 & 100 & 100 & $\mathbf{R} \%$ \\
200 & 4.29 & 42.17 & 73.26 & 100 & 100 & $\mathbf{R} \%$ \\
400 & 3.71 & 5.71 & 5.97 & 72.31 & 100 & $\mathbf{R} \%$ \\
600 & 3.11 & 3.24 & 5.35 & 35.23 & 99.8 & $\mathbf{R} \%$ \\
800 & 0.65 & 1.26 & 2.37 & 9.52 & 96.09 & $\mathbf{R} \%$ \\
\hline
\end{tabular}

$\mathrm{C}_{\mathrm{o} \text { RBBR }}=$ Initial Reactive Blue 19 dye concentration $(\mathrm{mg} / \mathrm{L}) ; \mathrm{C}_{\mathrm{o} \text { DTAB }}=$ Initial surfactant concentration $(\mathrm{mM})$. 
$\mathrm{pH}$ is an important parameter in solutions that contain oppositely charged molecules. It is known that the charge of the fungal biomass surface becomes positive at low $\mathrm{pH}$ values (Karatay et al., 2014). Recently, El-Sharaky et al. (2018) showed that the cationic metal removal efficiency of an anionic surfactant at $\mathrm{pH} 6$ and the removal process was related to the electrostatic interactions between metal ions and surfactant. Servaites et al. (2012) reported that the negative charged RB 19 dye bound to the positively charged protein molecules and the presence of negative charged surfactant SDS had no effect on the binding of RB 19 to the protein molecules. The RB 19 dye molecules charged negatively and DTAB became positive in the experimental system of this study. The surfactant and dye molecules interacted by electrostatic attractions and the reduction of the number of dye molecules observed in the flasks which contain only DTAB and dye, the surfactant and dye complex formed clusters and flocculated in the molasses medium. It was assumed that the content of molasses medium encouraged flocculation of surfactant molecules. Recently, Melo et al. (2017) reported that some natural ingredients can be used to form surfactant flocks in order to remove dye called Direct Yellow 27. In a recent study, similar results were shown by Melo et al. (2018) and this study was focused on removal of Reactive Blue 14 dye by ionic flocculation of surfactants. In the current study, the dye removal by flocculation process and by only fungal biomass without surfactant calculated as $98.88 \%$ and $2.86 \%$, respectively at $\mathrm{pH} 3$ (Figure 4). The fungal decolorization was very low because there was a little change in fungal biomass after 24 hours. On the other hand, the system included both fungal biomass and surfactant decolorized $100 \%$ of dye at $\mathrm{pH} 3$ after 24 hours maximally (Figure 4). Also, there was not any flock formation in the flask containing solution because the surfactant-dye complex was removed by the fungal biomass. The results supported that binary removal of dye and surfactant molecules by fungus took place in the decolorization process.

\subsection{The effect of surfactant and dye concentrations on bioremoval}

The effect of surfactant and dye concentration on RB 19 removal is given in Table 2. As seen in Table 2, while the surfactant concentrations were increasing, the dye removal rate of fungus was increased at all dye concentrations. Increasing dye concentration from 600 to $800 \mathrm{mg} / \mathrm{L}$ the decolorization rates were calculated as $99.8 \%$ and $96.09 \%$ in the presence of $2 \mathrm{mM} \mathrm{DTAB}$, respectively. The decolorization rates were $100 \%$ while the dye concentrations were increased from 100 to $400 \mathrm{mg} / \mathrm{L}$ in the presence of $2 \mathrm{mM}$ DTAB, maximally. Mirmohseni et al. (2012) studied the biosorption of the same dye RB 19 on chitosan fibers and reported that maximum RB 19 removal was $82.1 \%$ at $70 \mathrm{mg} / \mathrm{L}$ dye concentration. The cell wall of the A. versicolor fungus used in this study contained chitin/chitosan (Feofilova, 2010). Recently, Jimenez-Castaneda and Medina (2017) showed that surfactant modified clays and zeolite effectively used in wastewater treatment.
The results of this study supported that the negatively charged dye molecules were interacted with the functional components of fungal cell surface such as chitin/chitosan and the presence of positive charged surfactant DTAB enhanced these interactions. On the other hand, the removal of the dye-surfactant complex was determined as $100 \%$ at $2 \mathrm{mM}$ DTAB surfactant concentration in the current study. Klimiuk et al. (2006) showed that dye-modified chitin could be used as an adsorbent to remove oppositely charged surfactants from the water. This current study resulted that the surfactant molecules removed with the formation of a dye-surfactant complex by fungus. Also, the decolorization process finished with the result of $100 \%$ dye removal in a short time period. It is reported that the addition of surfactants reduced decolorization period and maintained both time and energy saving (Mnif et al., 2015). The results of this study showed that usage of surfactants in wastewater treatment ensure time and energy saving and also the removal of surfactants and dyes together in one treatment process as a cost-effective way.

\section{Conclusion}

The aim of this study was to investigate the binary removal of dye and surfactant molecules by a fungus called $A$. versicolor. Both dyes and surfactants are toxic pollutants and it is important to remove these pollutants together. The results of this study showed that the binary removal of both dye and surfactant molecules effectively occurred in the experimental design.

\section{References}

AKBAŞ, H. and TANER, T., 2013. The effect of electrolytes on the interaction of C. I. Reactive Orange 16-tetradecyltrimethylammonium bromide. Tenside, Surfactants, Detergents, vol. 50, no. 2, pp. 84-89. http://dx.doi.org/10.3139/113.110235.

ALEHYEN, S., BENSEJJAY, F., EL ACHOURI, M., PÉREZ, L. and INFANTE, M.R., 2010. Study of the interaction between methyl orange and mono and bis-quaternary ammonium surfactants. Journal of Surfactants and Detergents, vol. 13, no. 2, pp. 225-231. http://dx.doi.org/10.1007/s11743-009-1161-3.

BORCHERT, M. and LIBRA, J., 2001. Decolorization of reactive dyes by the white rot fungus Trametes versicolor in sequencing batch reactors. Biotechnology and Bioengineering, vol. 75, no. 3, pp. 313-321. http://dx.doi.org/10.1002/bit.10026. PMid:11590604.

CANER, N., KIRAN, I., ILHAN, S. and ISCEN, C.F., 2009. Isotherm and kinetic studies of Burazol Blue ED dye biosorption by dried anaerobic sludge. Journal of Hazardous Materials, vol. 165, no. 1-3, pp. 279-284. http://dx.doi.org/10.1016/j. jhazmat.2008.09.108. PMid:19013018.

EL-SHARAKY, E.A., MISHRIF, M.R. and EL-SHAMY, O.A.A., 2018. Synthesis and evaluation of a new trianionic surfactant for the removal of $\mathrm{Pb}$ (II) by flotation method. Tenside, Surfactants, Detergents, vol. 55, no. 2, pp. 148-152. http://dx.doi. org/10.3139/113.110545.

FEOFILOVA, E.P., 2010. The fungal cell wall: modern concepts of its composition and biological function. Microbiology, vol. 79, no. 6, pp. 711-720. http://dx.doi.org/10.1134/S0026261710060019. PMid:21774151. 
FREITAS, F., LUNARDI, S., SOUZA, L.B., VON DER OSTEN, J.S.C., ARRUDA, R., ANDRADE, R.L.T. and BATTIROLA, L.D., 2018. Accumulation of copper by the aquatic macrophyte Salvinia biloba Raddi (Salviniaceae). Brazilian Journal of Biology = Revista Brasileira de Biologia, vol. 78, no. 1, pp. 133-139. http://dx.doi.org/10.1590/1519-6984.166377. PMid:28699967.

GÜL, Ü.D. and DÖNMEZ, G., 2014. Influence of surfactants on dye removal and growth of Aspergillus versicolor: an effective way to decolorize textile dye. Clean Soil Air Water, vol. 42, no. 7, pp. 917-922. http://dx.doi.org/10.1002/clen.201200579.

HADIBARATA, T., YUSOFF, A.R.M. and KRISTANTI, R.A., 2012. Acceleration of anthraquinone-type dye removal by whiterot fungus under optimized environmental conditions. Water, Air, and Soil Pollution, vol. 223, no. 8, pp. 4669-4677. http://dx.doi. org/10.1007/s11270-012-1177-6.

HEIDARI, H. and KAHRIZI, D., 2018. Effect of water stress and contaminated water on seed germination traits and early growth in maize (Zea mays). Environmental Engineering and Management Journal, vol. 17, no. 1, pp. 35-42. http://dx.doi. org/10.30638/eemj.2018.005.

JIMENEZ-CASTANEDA, M.E. and MEDINA, D.I., 2017. Use of surfactant-modified zeolites and clays for the removal of heavy metals from water. Water, vol. 9, no. 4, pp. 1-12. http:// dx.doi.org/10.3390/w9040235.

KARATAY, S.E., GÜL, Ü.D. and DÖNMEZ, G., 2014. Determination of Methylene Blue biosorption by Rhizopus arrhizus in the presence of surfactants with different chemical structures. Preparative Biochemistry \& Biotechnology, vol. 44, no. 7, pp. 653-662. http://dx.doi.org/10.1080/10826068.2013.8 44710. PMid:24905046.

KARTHICK, K., NAMASIVAYAM, C. and PRAGASAN, L.A., 2018. Acceleration of anthraquinone-type dye removal by white-rot fungus under optimized environmental conditions. Environmental Progress \& Sustainable Energy, vol. 37, pp. 719732. http://dx.doi.org/10.1002/ep.12745.

KHALLADI, R., MOULAI-MOSTEFA, N. and BENTAHAR, F., 2018. Effect of nonionic surfactants on the removal of PAH from contaminated soil. Environmental Engineering and Management Journal, vol. 17, no. 2, pp. 327-335. http://dx.doi.org/10.30638/ eemj.2018.034.

KLIMIUK, E., GUSIATIN, Z. and KABARDO, K., 2006. The effectiveness of surfactants adsorption onto chitin and dyemodified chitin. Polish Journal of Environmental Studies, vol. 15, pp. 95-104.

LIU, H., OBENDORF, S.K., LEONARD, M.J., YOUNG, T.J. and INCORVIA, M.J., 2005. Adsorption of aroma chemicals on cotton fabric from aqueous systems. Journal of Surfactants and Detergents, vol. 8, no. 4, pp. 311-317. http://dx.doi.org/10.1007/ s11743-005-0361-3.

MAAS, R. and CHAUDHARI, S., 2005. Adsorption and biological decolorization of azo dye Reactive Red-2 in semicontinuous anaerobic reactors. Process Biochemistry, vol. 40, no. 2, pp. 699-705. http://dx.doi.org/10.1016/j.procbio.2004.01.038.
MELO, R.P.F., BARROS NETO, E.L., MOURA, M.C.P.A., DE CASTRO DANTAS, T.N., DANTAS NETO, A.A. and NUNES, S.K.S., 2017. Removal of Direct Yellow 27 dye by ionic flocculation: the use of an environmentally friendly surfactant. Journal of Surfactants and Detergents, vol. 20, no. 2, pp. 459-465. http://dx.doi.org/10.1007/s11743-016-1913-9.

MELO, R.P.F., BARROS NETO, E.L., NUNES, S.K.S., CASTRO DANTAS, T.N. and DANTAS NETO, A.A., 2018. Removal of Reactive Blue 14 dye using micellar solubilization followed by ionic flocculation of surfactants. Separation and Purification Technology, vol. 19, pp. 161-166. http://dx.doi.org/10.1016/j. seppur.2017.09.029.

MIRMOHSENI, A., SEYED DORRAJI, M.S., FIGOLI, A. and TASSELLI, F., 2012. Chitosan hollow fibers as effective biosorbent toward dye: preparation and modeling. Bioresource Technology, vol. 121, pp. 212-220. http://dx.doi.org/10.1016/j. biortech.2012.06.067. PMid:22858488.

MNIF, I., FENDRI, R. and GHRIBI, D., 2015. Biosorption of Congo Red from aqueous solution by Bacillus weihenstephanensis RI12: effect of SPB1 biosurfactant addition on biodecolorization potency. Water Science and Technology, vol. 72, no. 6, pp. 865874. http://dx.doi.org/10.2166/wst.2015.288. PMid:26360745.

OUNI, H., HAFIANE, A. and DHAHBI, M., 2015. The effect of surfactant on dye removal by polyelectrolyte enhanced ultrafiltration. Desalination and Water Treatment, vol. 56, no. 6, pp. 1526-1535. http://dx.doi.org/10.1080/19443994.2014.952670.

PRZYSTAŚ, W., ZABŁOCKA-GODLEWSKA, E. and GRABIŃSKA-SOTA, E., 2013. Effectiveness of dyes removal by mixed fungal cultures and toxicity of their metabolites. Water, Air, and Soil Pollution, vol. 224, no. 5, pp. 1534. http://dx.doi. org/10.1007/s11270-013-1534-0. PMid:23687394.

RAMÍREZ, M.E., VÉLEZ, Y.H., RENDÓN, L. and ALZATE, E., 2018. Potential of microalgae in the bioremediation of water with chloride content. Brazilian Journal of Biology $=$ Revista Brasileira de Biologia, vol. 78, no. 3, pp. 472-476. http://dx.doi. org/10.1590/1519-6984.169372. PMid:29069164.

RODRÍGUEZ COUTO, S., 2009. Dye removal by immobilized fungi. Biotechnology Advances, vol. 27, no. 3, pp. 227-235. http:// dx.doi.org/10.1016/j.biotechadv.2008.12.001. PMid:19211032.

ROUSK, J., BROOKES, P.C. and BÅÅTH, E., 2009. Contrasting soil $\mathrm{pH}$ effects on fungal and bacterial growth suggest functional redundancy in carbon mineralization. Applied and Environmental Microbiology, vol. 75, no. 6, pp. 1589-1596. http://dx.doi. org/10.1128/AEM.02775-08. PMid:19151179.

SERVAITES, J.C., FAETH, S. and SIDHU, S., 2012. A dye binding method for measurement of total protein in microalgae. Analytical Biochemistry, vol. 421, no. 1, pp. 75-80. http://dx.doi. org/10.1016/j.ab.2011.10.047. PMid:22138185.

TAŞTAN, B.E., ERTUĞRUL, S. and DÖNMEZ, G., 2010. Effective bioremoval of a reactive dye and heavy metals by Aspergillus versicolor. Bioresource Technology, vol. 101, no. 3, pp. 870-876. http://dx.doi.org/10.1016/j.biortech.2009.08.099. PMid:19773159. 